Canadian Journal of Civil Engineering

Canadian

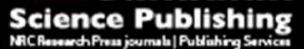
Revue canadienne de génie civil

\title{
Seismic Fragility Analysis of Pre-1975 Conventional Concrete Frame Buildings in Canada
}

\begin{tabular}{|r|l|}
\hline Journal: & Canadian Journal of Civil Engineering \\
\hline Manuscript ID & cjce-2017-0238.R2 \\
\hline Danuscript Type: & Article \\
\hline $\begin{array}{r}\text { Complete List of Authors: } \\
\text { Is the invited manuscript for } \\
\text { consideration in a Special } \\
\text { Issue? : }\end{array}$ & Not Mamun, Abdullah; University of Ottawa, Civil Engineering \\
\hline Keyword: & $\begin{array}{l}\text { Conventional concrete buildings, ductile concrete buildings, moderately } \\
\text { ductile concrete buildings, seismic fragility curves, seismic vulnerability } \\
\text { assessment }\end{array}$ \\
\hline &
\end{tabular}

SCHOLARONE $^{\text {m }}$

Manuscripts 


\section{Seismic Fragility Analysis of Pre-1975 Conventional}

2 Concrete Frame Buildings in Canada

3 Abdullah Al Mamun and Murat Saatcioglu

4

5 Abdullah Al Mamun, and Murat Saatcioglu. Department of Civil Engineering, University of

6 Ottawa, 161 Louis Pasteur, Ottawa, ON K1N6N5

7 Corresponding Author: Murat Saatcioglu (e-mail:Murat.Saatcioglu@uottawa.ca), Department

8 of Civil Engineering, University of Ottawa, 161 Louis Pasteur, Ottawa, ON K1N6N5. Office:

$9 \quad 613562-5800$ ext. 6129.

10 Word Count: 8029

11

12

13

14

15

16

17 
18 Abstract: Fragility analysis was conducted for reinforced concrete frame buildings in Canada

19 designed based on the 1965 National Building Code of Canada as representative of pre-1975 era

20 of seismic design practice. 2-, 5- and 10-storey buildings were designed for Vancouver and

21 Ottawa, representing buildings in high and medium seismic regions. They were modelled for

22 inelastic response time history analysis, with respective inelastic hysteretic models for flexure

23 and shear. Software PERFORM-3D was used to conduct incremental dynamic analysis under

24 incrementally increasing earthquake intensity. Probabilistic analysis of the results of incremental

25 dynamic analysis led to the development of fragility functions, which can be used as seismic

26 vulnerability assessment tools. The results are compared with those generated for frame

27 buildings designed on the basis of the 2010 NBCC. The comparison indicates that the

28 probabilities of exceeding performance levels are significantly higher for older buildings relative

29 to recently built fully ductile and moderately ductile buildings, respectively.

30 Keywords: Conventional concrete buildings, ductile concrete buildings, moderately ductile

31 concrete buildings, NBCC, reinforced concrete frame buildings, seismic design, seismic fragility

32 curves, seismic performance, seismic vulnerability assessment. 


\section{Introduction}

Seismic design requirements in the National Building Code of Canada (NBCC) have evolved

41 over the years. The procedure for determining seismic shear forces improved since its inception

42 in 1941. The effects of dynamic characteristics of structures, ductility demands for energy

43 dissipation, and improved seismic hazard values were implemented as the knowledge on

44 earthquake engineering has advanced. Older buildings designed prior to the enactment of modern

45 seismic codes remain vulnerable to earthquakes. The current research project addresses seismic

46 assessment of reinforced concrete frame buildings designed and built prior to the implementation

47 of ductile design provisions using a probabilistic approach. Fragility curves, relating seismic

48 hazard to probability of exceeding pre-selected performance levels, have been developed for

49 representative concrete frame buildings designed by the 1965 NBCC (NRCC 1965). The fragility

50 curves and the results of seismic vulnerability assessment are presented for Vancouver, located

51 in a high seismic region; and Ottawa, located in a moderate seismic region. The results are

52 compared with earlier fragility analysis conducted by the authors (Al Mamun and Saatcioglu

53 2017) for ductile and moderately ductile buildings in Canada conforming to the more recent

542010 NBCC (NRCC 2010) seismic provisions.

55 Seismic fragility curves provide a convenient procedure to assess vulnerability of structures

56 against seismic hazards. Though limited research was conducted in Canada on seismic fragility

57 analysis, Ventura et al. (2005) developed fragility curves for southwest British Columbia

58 involving different categories of buildings. Similar research was also conducted in the US,

59 Europe and Asia for employing fragility analysis for seismic risk assessment (Lupoi et al 2006;

60 Ramamoorthy et al. 2008; Buratti et al. 2010; Rajeev and Tesfamariam 2012; Bilgin 2013; Jeong

61 et al. 2007). 
The 1941 National Building Code (NRCC 1941) defined base shear as percentage of building

63 mass, which varied with the bearing capacity of soil. The 1953 NBCC (NRCC 1953) was the

64 first edition where seismic hazard was expressed in terms of seismic zones, and a zoning map

65 was used to calculate the base shear. In the 1965 NBCC, ultimate strength design was permitted

66 as an alternative method and capacity reduction factors were introduced. Importance factor and

67 foundation factor were also introduced as improvements that affected seismic base shear. In the

681970 NBCC (NRCC 1970), the base shear equation was modified to accommodate the effect of

69 fundamental period. The seismic zoning map was revised. The advantage of structural ductility

70 was recognized for the first time and a new factor was introduced to account for the ductility of

71 structural system as affected by construction type. In the 1975 NBCC (NRCC 1975), the base

72 shear equation was revised and dynamic analysis was permitted as an alternative method. In

731977 (NRCC 1977), the base shear computed by dynamic analysis was limited not to be less than

74 the $90 \%$ of the value computed using the equivalent static load procedure. The requirements

75 remained the same in the 1980 NBCC (NRCC 1980) with a small change in calculating seismic

76 response factor, S. New seismic zoning maps were introduced in the 1985 NBCC (NRCC 1985).

77 The base shear computed through dynamic analysis was limited not to be less than $100 \%$ of the

78 value computed by the equivalent static load procedure. In the 1990 NBCC (NRCC 1990), force

79 modification factor based on ductility demand was considered in computing base shear with

80 revised equations for fundamental periods of frame buildings introduced in 1995 (NRCC 1995).

81 Major revisions were introduced to the NBCC in the 2005 edition (NRCC 2005). New hazard

82 values were introduced in the form of site-specific uniform hazard spectra (UHS). The equation

83 for fundamental period of frame structures was revised. Factors for higher mode effects as well

84 as coefficients for acceleration and velocity based foundation effects were introduced. A new set 
85 of force modification factors for over-strength and ductility were included with a refined 86 classification of seismic force resisting systems. Dynamic analysis was made the preferred 87 method of analysis with restrictions for the equivalent static force procedure. The 2010 NBCC 88 and 2015 NBCC (NRCC 2015) requirements remained essentially the same with improved 89 hazard values and some minor modifications. Figure 1 illustrates the variation of seismic base 90 shear over the years for six reinforced concrete frame buildings, three in Vancouver, and the 91 other three in Ottawa. The buildings have 2, 5 and 10 storey heights. Because there was no 92 distinction in seismic zones between Ottawa and Vancouver prior to 1970, and there was no 93 ductile design and detailing requirements prior to 1975, the design base shear in both cities were 94 the same, and the buildings were designed to have conventional, non-ductile frame systems. The 951970 NBCC was the exception, which made a distinction between non-ductile and ductile 96 structural systems though ductile design and detailing were not implemented. Figure 1 also 97 includes design base shears after 1975 with two levels of ductility; fully ductile for Vancouver 98 and moderately ductile for Ottawa. Further details of the evolution of NBCC seismic provisions 99 are provided by Mitchell et al. (2010).

100 In addition to the evolution of seismic base shear calculations outlined in the NBCC, the 101 requirements for design and detailing of reinforcement in concrete buildings, specified in CSA 102 A23.3 (CSA), also evolved over the years. These requirements were first introduced in CSA 103 A23.3-1973 (CSA 1973), which was referenced in the 1975 NBCC. Though ductile design and 104 detailing requirements were first introduced in 1973, the ductility based $\mathrm{K}$ factor to account for 105 different types of construction had been introduced in the 1970 NBCC. Hence, buildings 106 constructed prior to 1975 were considered in the current investigation as old conventional 107 buildings. Significant improvements were introduced in CSA A23.3 (CSA 1984) after 1984 with 
108 the introduction of capacity design requirements, protecting critical elements and preventing 109 non-ductile failures.

110 Considering the evolution of seismic design practices in Canada, summarized above, the

111 concrete frame building inventory may be viewed in two categories; buildings designed prior to

112 1975, and those designed using the ductile design requirements of the post-1975 era. The current

113 paper focuses on buildings in the former category. It includes seismic assessment of non-ductile

114 frame buildings built between 1953 and 1975. The design base shear remained approximately the

115 same in this period, with lowest values given by the 1965 NBCC. The 1965 design was taken as

116 the representative design for the era. This would result in somewhat conservative assessment of

117 buildings designed for higher base shears. Table 1 includes the details for column and beam

118 designs based on the 1965 NBCC.

119 The non-ductile frame buildings designed for the 1965 NBBC were modelled for non-linear 120 dynamic analysis. The structural models were then used to conduct non-linear time history 121 analysis using computer software PERFORM-3D (CSI 2013). The analysis was repeated under 122 different earthquake intensities to implement the incremental dynamic analysis procedure from 123 which fragility curves were obtained through probabilistic evaluation of results.

124 The fragility curves derived are compared with those developed earlier for the 2010 NBCC 125 buildings (Al Mamun and Saatcioglu 2017) to illustrate differences in seismic vulnerabilities of 126 older and newer frame buildings in Canada. In addition, two other comparisons are made to 127 assess the significance of the change in building design practices between 1965 and 2010. First, 128 the mean annual frequency of collapse was computed for each set of structures, and compared. 129 Secondly, push-over analyses were performed to assess the performance under incrementally 130 increasing static forces. The results are presented and discussed in the paper. 


\section{Building Details and Analysis Approach}

132 2-, 5- and 10-storey reinforced concrete frame buildings with $8 \mathrm{~m}, 20 \mathrm{~m}$ and $40 \mathrm{~m}$ heights,

133 respectively, were considered as representative structures for buildings having regular structural

134 layouts. All the buildings had identical 5 bays in each direction; having a $7 \mathrm{~m}$ span, resulting in a

$13535 \mathrm{~m}$ by $35 \mathrm{~m}$ square plan. Figure 2(a) shows a three dimensional view of the 5 -storey building

136 modeled in ETABS software (CSI 2008). The buildings were designed for $1.33 \mathrm{kPa}$

137 superimposed dead load in addition to their self-weight, and $2.44 \mathrm{kPa}$ live load. The lateral

138 seismic base shear (V) was calculated according to the equation provided in the 1965 NBCC,

$139 \mathrm{~V}=\mathrm{RCIFSW}$, where seismic regionalization factor $\mathrm{R}=4$, construction factor $\mathrm{C}=0.75$,

140 importance factor $\mathrm{I}=1$, foundation factor $\mathrm{F}=1$, structural flexibility factor $\mathrm{S}=0.25 /(\mathrm{N}+5)$ for $\mathrm{N}$ -

141 storey structure and weight of the structure W. Which resulted in the same design for buildings

142 in Vancouver and Ottawa, as there was no distinction between the two regions at the time. The

143 buildings were analyzed for the load combinations specified in the code. The compressive

144 strength of concrete $\left(f_{c}^{\prime}\right)$ used was $30 \mathrm{MPa}$ for 2- and 5-storey buildings and $40 \mathrm{MPa}$ for the 10-

145 storey building. Yield strength of reinforcement was $400 \mathrm{MPa}$ for all designs.

146 Seismic records selected for non-linear dynamic analysis were compatible with the UHS 147 specified in the 2010 NBCC. They consisted of 20 earthquake records (Gail Atkinson 2009) for 148 each of the two regions considered, i.e., eastern and western Canada, adapted to the UHS for 149 Ottawa and Vancouver, respectively. For Ottawa, M6 earthquakes were selected with epicentral 150 distances of $10-15 \mathrm{~km}$ and $20-30 \mathrm{~km}$; and $\mathrm{M} 7$ earthquakes were selected with epicentral 151 distances of 15-25 km and 50-100 km. For Vancouver, M6.5 earthquake was selected with 152 epicentral distances of $10-15 \mathrm{~km}$ and $20-30 \mathrm{~km}$; and M7.5 earthquake was selected with $15-25$ $153 \mathrm{~km}$ and $50-100 \mathrm{~km}$. The algorithm proposed by Vamvatsikos and Cornell (2004) was used to 
154 increase or decrease the intensity of records to perform incremental dynamic analysis (IDA).

155 Further details of the seismic records and the implementation of the IDA are provided by the

156 authors relative to the fragility analysis of newer buildings that conform to the $2010 \mathrm{NBCC}$ (Al

157 Mamun and Saatcioglu 2017).

158 The fragility analysis required a seismic intensity measure and damage indices for

159 performance limits. The intensity measure used in the IDA was the spectral acceleration at the

160 fundamental period $\left(\mathrm{T}_{\mathrm{e}}\right)$ of the structure. The inter-storey drift ratio was adopted as the damage

161 indicator. Three damage states were considered corresponding to three performance levels as

162 commonly accepted performance limits; i) Immediate Occupancy (IO), ii) Life Safety (LS), and

163 iii) Collapse prevention (CP) (ASCE 2014; FEMA 2000a; ACI 2013). Immediate Occupancy

164 (IO) performance level describes the damage state where structure is safe to be re-occupied

165 having suffered minor damage to the structural elements with minor spalling and flexural

166 cracking. The inter-storey drift of $1 \%$ was considered for this limit state. Life Safety (LS)

167 performance level describes the damage state where significant damage has occurred to the

168 structure with extensive cracking and hinge formation in primary structural elements. The inter-

169 storey drift of $2 \%$ was adopted for this limit state. Collapse Prevention (CP) performance level

170 describes the damage state where structure is at the onset of partial or total collapse with

171 extensive cracking, hinge formation and reinforcement buckling in structural elements. The

172 median value of maximum inter-storey drift demands for all records was considered as $\mathrm{CP}$

173 performance level. This approach was also used by Ellingwood et al. (2007). The maximum

174 inter-storey drift for CP limit was obtained as the smaller of the drift at which either dynamic

175 instability is attained or the tangential slope of the IDA curve dropped to $20 \%$ of the initial slope

176 (FEMA 350). 
177 The conditional probability of exceeding a certain limit state (LS) at a given spectral

178 acceleration $\left(S_{a}\left(T_{e}\right)\right)$ was expressed by Jeong et al. (2007) as shown below in Equation 1.

179

(1) $P(D / I M)=1-\phi\left(\frac{\ln D_{C}-\ln D_{M}}{\sqrt{\left(\beta_{\frac{D}{M}}^{2}+\beta_{C}^{2}+\beta_{M}^{2}\right)}}\right)$

180 Where, $D_{C}$ is the median drift capacity specified for a certain limit state. $\beta_{D / M}$ denotes

181 standard deviation of $\log$ of deformation demand and assumed to be constant over the spectral

182 acceleration range; $\beta_{C}$ denotes standard deviation of log of deformation capacity and is taken as

$183 \quad 0.3$ (Jeong and Elnashai 2007) for all limit states, and $\beta_{M}$ denotes uncertainty in analytical

184 modeling and is taken as 0.2 on the assumption that the modelling process yields frame response

185 with $90 \%$ confidence and within $30 \%$ of actual value (Ellingwood et al. 2007); $D_{M}$ is the median

186 drift demand and is defined as $D_{M}=a \cdot S_{a}\left(T_{e}\right)^{b}$ where a and b are regression coefficients that

187 are found from the 'cloud' analysis.

188 The outcome of fragility analysis was used to establish the mean annual frequency of collapse

$189\left(\lambda_{c}\right) \cdot \lambda_{c}$ was calculated for each structure by integrating collapse fragility curve with site specific

190 seismic hazard. The same approach was used by previous researchers to assess seismic collapse

191 performance of buildings (Bradley and Dhakal 2008; Goulet et al. 2007; Haselton 2006). The

192 following equation specified by Ibarra and Krawinkler (2005) was used to calculate $\lambda_{c}$ :

$193 \quad(2) \quad \lambda_{c}=\int_{0}^{\infty} F_{C, S_{a, C}}(x) \cdot v \cdot f_{S_{a}}(x) \cdot d x$

194 where $F_{C, S_{a, C}}(x)$ represents probability of exceeding certain spectral acceleration, $x$, 195 corresponding to the collapse fragility curve, $v$ represented annual probability of exceedance of 196 certain rate of seismicity, $x$ and $f_{S_{a}}(x)$ represented the probability density function at certain 197 spectral acceleration value, $x$. Return periods associated with $2 \%$ and $10 \%$ probability in 50 -year 
198 hazard values for spectral accelerations for Ottawa and Vancouver were obtained from

199 Geological Survey of Canada (Adams and Halchuk 2003), and were used to calculate annual

200 probability of exceedance $(v)$.

201 Pushover analysis was also performed to determine the static lateral seismic force resistances

202 of structures. Yield base shear capacity was established through idealized bilinear force 203 deformation relationship according to FEMA 356 (FEMA 2000). Since the cracked stiffness was

204 used to model structural members, linear cracked slope of the load deformation curve was found 205 as effective stiffness of the structure. Yield shear force $\left(V_{y}\right)$ and yield roof drift $\left(\delta_{y}\right)$ in idealized 206 bilinear curve was calculated by using site specific UHS in the 2010 NBCC. From push-over 207 analysis, over-strength factor $\left(R_{0}\right)$ for each building was calculated as the ratio of yield shear 208 capacity $\left(\mathrm{V}_{\mathrm{y}}\right)$ to design base shear $\left(\mathrm{V}_{\mathrm{d}}\right)$. Displacement ductility $(\mu)$ of a building was calculated 209 as the ratio of maximum roof drift $\left(\delta_{\mathrm{u}}\right)$ corresponding to 0.8 times the maximum shear strength $210\left(\mathrm{~V}_{\max }\right)$ to yield roof $\mathrm{drift}\left(\delta_{\mathrm{y}}\right)$

\section{3. Analytical Models}

212 The buildings were modeled using software PERFORM-3D. Beams and columns were

213 modeled using two segments, each consisting of an elastic frame element with an inelastic hinge

214 at the end, connected together at the point of inflection. Figure 2(b) shows the schematic diagram

215 for a reinforced concrete frame in the analytical model. Elastic frame elements were assigned 216 linear elastic properties with plastic deformations lumped at the hinges. Both flexural and shear

217 hinges were provided. A rigid end zone was specified at the end of each structural element to 218 eliminate deformations within the adjoining member, ensuring that potential plastic hinges form 219 at the face of the adjoining member rather than at their centrelines. Energy degradation factor 
220 (EDF) was used to introduce stiffness degrading hysteretic behaviour in flexure and shear as 221 typically observed in reinforced concrete elements.

222 A tri-linear envelop curve was used for modelling moment-rotation hysteretic relationship.

223 The initial linear segment represented the effective cracked stiffness based on $35 \%$ and $70 \%$ of 224 uncracked flexural rigidities for beams and columns, respectively as per CSA A23.3-14. The 225 reduction in stiffness values was suggested in the NBCC-1965, but no specific value was 226 indicated for the amount of reduction to be applied. The yield moment was calculated from 227 sectional analysis with the corresponding chord rotation at yield calculated as $\frac{\mathrm{ML}}{6 \mathrm{EI}}$, where $\mathrm{M}$ 228 represents the yield moment, L represents the member length, E represents the elastic modulus of 229 concrete, and I represents the effective moment of inertia of the section. The second linear 230 segment in the post yield range was established by assuming post-yield slopes of $8.5 \%$ and $4 \%$ 231 of effective elastic slopes for beams and columns, respectively. The post yield segment 232 continued up to an ultimate rotation of 1.5 times the yield rotation prior to the onset of strength 233 decay. The descending branch, which ended at the residual strength, was based on the ASCE4123413 recommendation. The strength decay slope for both beams and columns was adopted from 235 ASCE41-13 (ASCE 2014) for flexure-controlled response with nonconforming transverse 236 reinforcement. The residual strength for beams was specified as $20 \%$ of maximum capacity. It 237 varied between $0 \%$ and $20 \%$ of maximum capacity for columns depending on the accompanying 238 level of axial load. Figure 3 illustrates the moment-rotation envelope used for the model in 239 PERFORM-3D.

240 Once the primary curve was defined, the next step involved the computation of energy 241 degradation factor (EDF), which introduced stiffness degradation characteristics of reinforced242 concrete elements under reversed cyclic loading. EDF is the ratio of area under degraded cycle to 
243 fully elastoplastic non-degraded cycle. This factor changes the hysteretic behaviour from 244 perfectly elasto-plastic behaviour to stiffness degrading behaviour that is typically observed in 245 reinforced concrete elements as illustrated in Fig. 4. The value for EDF was established by 246 examining experimental data. Column tests conducted by Ozcebec and Saatcioglu (1989) were 247 used for this purpose. The force-displacement hysteretic response of test column U1, obtained by 248 testing a $350 \mathrm{~mm}$ square column having $1.0 \mathrm{~m}$ shear span, 3.3\% longitudinal reinforcement and $2490.85 \%$ transverse reinforcement, was used to define the flexural EDF as shown in Fig. 4(a). 250 Accordingly the EDF value of 0.50 was found to match the experimental data. The same EDF 251 value was used for both beams and columns.

252 The shear behaviour was also modelled with a tri-linear envelop curve for both beams and 253 columns. A linear variation was considered for shear force-shear distortion relationship up to 254 concrete shear capacity $\left(V_{c}\right)$ and corresponding shear strain $\left(\gamma_{c}\right)$, where $\gamma_{c}=\frac{V_{c}}{G A_{v}}, A_{v}$ is shear 255 area and $G$ is shear rigidity. The second linear segment continued with a positive slope, but with 256 a reduced shear rigidity $G_{E}=0.1 G$. This branch continued up to total shear capacity $\left(V=V_{c}+\right.$ $\left.257 V_{S}\right)$, consisting of concrete and transverse steel contributions $\left(V_{s}\right)$. The total shear strain $(\gamma)$ at this 258 level was calculated as $\gamma=\gamma_{c}+\gamma_{s}$ where $\gamma_{s}=\frac{V_{S}}{G_{E} A_{v}}$. Shear displacement $(\Delta)$ was calculated as $259 \Delta=0.5 \gamma h$ where $0.5 \mathrm{~h}$ corresponds to hinge length $(50 \%$ of member depth, $h)$. The third line 260 segment with a descending slope was obtained from the ASCE41-13 recommendation specified 261 for beam-column joints. The values specified in ASCE 41-13 for elements with nonconforming 262 transverse reinforcement and axial loads of less than $10 \%$ of $A_{g} f_{c}^{\prime}$ (where $A_{g}$ is gross concrete 263 area) were used for both beams and exterior columns. For the interior columns, the value for 264 axial loads greater than $40 \% A_{g} f_{c}^{\prime}$ was used. Residual shear capacity was considered to be $20 \%$ 
265 of beam and exterior column shear capacities, and $0 \%$ for interior column capacity. It was found 266 that the degradation slope of shear force-shear displacement backbone curve was between 2 to $2673 \%$ of initial slope for both beams and columns. The EDF for shear was based on experimental 268 data. The hysteretic shear force-displacement relationship experimentally obtained by Ozcebec 269 and Saatcioglu (1987) was used as shown in Fig. 4(b). Among the columns tested, the test 270 column U1 was considered as representative of shear behaviour. The same EDF values were 271 used both for beams and columns with values of 0.44 up to the end of the first line segment and 2720.29 thereafter.

\section{4. Performance Assessment of the Buildings}

The results of dynamic analysis of buildings designed based on the 1965 NBCC indicated that

275 beam hinging was observed as early as $1 \%$ storey drift, with the first storey columns also 276 experiencing inelasticity. This implies that at the IO performance level, inelastic hinging has 277 already started. These buildings never developed the $2 \%$ inter-storey drift associated with LS 278 performance; and failed prior to reaching this limit state. Indeed, the CP limit state was reached 279 on average at $1.5 \%$ storey drift, indicating that older buildings could collapse prior to developing 280 the assumed life safety performance. In the 2-storey building analysed, flexural hinges formed in 281 the $2^{\text {nd }}$ floor beams, which were followed by the $1^{\text {st }}$ floor columns. A similar trend was observed 282 in reaching ultimate moment capacities of members. For all cases, the beams developed failure at 283 the $1^{\text {st }}$ floor level first, followed by the $1^{\text {st }}$ floor columns. Shear hinges formed in the $1^{\text {st }}$ floor 284 columns at the same time as flexural hinges. Though column shear demands exceeded concrete 285 shear capacity, no shear failure was observed. The 5-storey building experienced shear hinging 286 first in the $1^{\text {st }}$ floor interior columns, followed by flexural hinging of the $2^{\text {nd }}$ floor exterior beams.

287 Subsequently, flexural hinging extended to the $2^{\text {nd }}, 3^{\text {rd }}$ and $4^{\text {th }}$ floor beams, followed by the 
288 flexural hinging of the $1^{\text {st }}$ floor columns. The failure was caused by insufficient flexural capacity 289 in the $1^{\text {st }}$ floor columns. A similar trend was observed in the 10 -storey building; flexural hinging 290 started forming in the $2^{\text {nd }}$ floor beams and then gradually propagated up to the $6^{\text {th }}$ floor level. 291 Shear hinging occurred in the ground floor columns, followed by flexural hinging. The failure 292 was due to insufficient shear capacity of these columns under high intensity excitations. The 293 beams were not critical in shear, and there was no beam-shear hinging observed in any of the 294 buildings.

295 The fragility analysis indicates that the 1965 buildings in Vancouver show 93\% to 99\% 296 probability of exceeding the IO performance level at 2010 NBCC hazard levels. The same 297 buildings under the same intensity levels show $68 \%$ to $91 \%$ probability of exceeding the $\mathrm{CP}$ 298 level. The 1965 buildings in Ottawa showed somewhat lower probabilities of exceedances, 299 showing $11 \%$ to $30 \%$ probability of exceeding the IO limit, and $1 \%$ to $9 \%$ probability of 300 exceeding the CP limit state. Figure 5 shows the fragility curves for all the 1965 buildings 301 located in Vancouver and Ottawa. The same figure also includes the fragility curves developed 302 by the authors (Al Mamun and Saatcioglu 2017) for the same buildings designed using the 2010 303 NBCC requirements with design details illustrated in Table 1. A similar comparison is given in 304 Table 2. It can be observed from Table 2 that at IO performance level, all the 1965 buildings 305 exhibit similar response as those for the 2010 buildings. At the CP limit state, the 1965 buildings 306 in Ottawa and Vancouver show on the average $6 \%$ and $76 \%$ higher probabilities of exceedance 307 relative to the 2010 buildings, respectively. Demand standard deviation $\left(\beta_{D / M}\right)$ associated to 308 develop fragility function for 1965 buildings was 0.19 ; and for 2010 buildings located in Ottawa 309 and Vancouver was 0.20 and 0.19 , respectively. 
310 Further comparisons of older and more recent building performances indicate that the

311 maximum inter-storey drift ratio $\left(\delta_{\max }\right)$ attained in the 1965 buildings are lower than those for the

3122010 buildings. This is shown in Table 2, and is expected because of the brittle performance of

313 older buildings. It is noteworthy that all the buildings had approximately the same yield drift

314 capacities. This implies that the ductility levels considered in design are reflected in the analysis

315 results. The ultimate flexural rotations of structural elements in the 1965 buildings developed 1.5

316 times their yield rotations; whereas the members in the 2010 buildings showed 2.5 and 4.0 times

317 the yield rotation for buildings in Ottawa and Vancouver corresponding to moderately and fully

318 ductile buildings.

319 The comparisons extended to include annual probability of exceedances. Figure 6 shows the

320 graphical representation for calculating annual probability of exceedance ( $v$ ) for the 2-storey

3212010 building in Vancouver. Figure 7 graphically shows the approach for calculating the mean

322 annual frequency of collapse $\left(\lambda_{c}\right)$ for the same building at design spectral acceleration

323 corresponding to the empirical code period $\left(S_{a}\left(T_{d}\right)=x\right)$. In the figure, $f_{S_{a}}(x)$ is developed

324 from probability distribution function at $S_{a}\left(T_{d}\right)$ observed in IDA and $F_{C, S_{a, C}}(x)$ is obtained from

325 fragility response. Table 2 indicates that the 2010 Ottawa buildings have the lowest mean annual

326 frequency of collapse $\left(\lambda_{c}\right)$, whereas the 1965 Vancouver buildings have the highest $\lambda_{c}$.

327 Push-over analysis was also used to compare the performances of the 1965 and 2010

328 buildings. Figure 8 shows the comparison of push-over responses for 2-, 5- and 10-storey

329 buildings. Figure 9 shows a bilinear idealization of the push-over response for the 2-storey 2010

330 building in Vancouver. Table 2 compares shear force responses obtained through push-over

331 analyses of buildings. It indicates that the 2010 buildings in Vancouver have higher shear

332 capacities, relative to the 1965 buildings. On average, the maximum shear capacity of 2010 
333 Ottawa and Vancouver buildings are 26\% and 56\% higher than those for the 1965 buildings,

334 respectively. Similar trend is observed for the maximum roof drift ratio $\left(\delta_{u}\right)$. Ottawa buildings

335 show lower maximum roof displacements relative to the buildings in Vancouver. Over-strength

336 ratio $\left(R_{0}\right)$ obtained from the push-over analysis of 2010 Ottawa and Vancouver buildings are on

337 average $39 \%$ and $76 \%$ higher than those for 1965 buildings, respectively. For the 5- and 10-

338 storey 1965 buildings, the maximum shear capacity $\left(\mathrm{V}_{\max }\right)$ is less than the design shear strength

$339\left(V_{d}\right)$, which implies over-strength ratios $\left(R_{o}\right)$ of less than 1.0. Insufficient shear capacity and low

340 ductility of structural elements explain the poor performance of 1965 buildings observed in the

341 comparison. Though structural members were detailed for a ductility-related force modification

342 factors of 1.5 for the 1965 building, and 2.5 and 4.0 for the 2010 buildings in Ottawa and

343 Vancouver, respectively, the average global ductility demands based on roof displacements are

3441.6 for the 1965 buildings, and 2.7 and 2.6 for the 2010 buildings in Ottawa and Vancouver,

345 respectively.

346 Figures 10(a) and 11(a) show the effect of global ductility ratio $(\mu)$ on mean annual collapse

347 frequency $\left(\lambda_{c}\right)$ of buildings. It is observed that for a given building; the mean annual collapse

348 frequency decreases with increasing building ductility. Similarly, the mean annual collapse

349 frequency $\left(\lambda_{c}\right)$ decreases with increasing over-strength ratio $\left(R_{o}\right)$, as shown in Figs. $10(b)$ and

350 11(b). The same trend was observed for all building height considered (2-, 5- and 10-storey).

351 This suggests that the seismic safety margin can be increased with increasing ductility $(\mu)$ and

352 over-strength $\left(\mathrm{R}_{\mathrm{o}}\right)$.

353 The fragility analysis included the uncertainties involved in developing analytical models in

354 predicting deformation demands and capacities of buildings. However, the fragility response

355 might be adjusted due to the variations in material strength in older buildings. Rajeev and 
356 Tesfamariam (2012) indicated that for 3-storey to 9-storey buildings with a wide variation in the

357 properties of construction materials used (40\% reduction in concrete strength and steel strength

358 as well as $40 \%$ change in ties and stirrup spacing) resulted $29 \%$ change in deformation demands.

359 One of the limitations of the analytical model employed in developing the fragility curves was

360 the assumption of rigid beam-column joints. Joint behaviour in pre-seismic design era can be

361 affected by excessive cracking of joints, depending on numerous design parameters and the

362 resulting softening in joints. Bonacci and Pantazopouou (1993) investigated the significance of

363 joint softening in reinforced concrete frame buildings by examining a wide range of parameters.

364 They concluded that it was difficult to draw a generalized conclusion on the effect of joint

365 softening on structural response while pointing out that a large number of parameters affect joint

366 behavior. The researchers also indicated that the effect of joint softening can be small for frames

367 with weak beams, where the energy dissipation is concentrated in the beam hinge regions, and

368 yet can be significant if extensive diagonal joint cracking occurs in the absence of joint

369 transverse reinforcement, especially if the column size is small with reduced concrete shear

370 resistance in joints. Clearly, the softening effect of beam-column joints increases with increased

371 inelastic drift demands.

\section{5. Summary and Conclusions}

373 Three reinforced concrete frame buildings were designed based on the 1965 NBCC for

374 seismic vulnerability analysis of buildings in Ottawa and Vancouver, as representative cities

375 located in medium and high seismic regions in Canada. The buildings had 2-, 5- and 10-storey

376 heights, and were designed as conventional buildings without the ductile seismic detailing

377 required in current seismic codes. Dynamic inelastic response history analyses were conducted 
378 using computer software PERFORM-3D under site specific earthquake records. Incremental

379 dynamic analyses were performed under incrementally increasing seismic intensity, based of

380 spectrum intensity as the intensity measure. The results were evaluated for different performance

381 levels as dictated by corresponding damage indices, where inter-storey drift was adopted as the

382 damage indicator. Commonly accepted performance levels, defined as immediate occupancy, life

383 safety and collapse prevention were used. It was observed that the collapse prevention limit state

384 was exceeded prior to developing the commonly accepted $2 \%$ storey drift as the life safety limit.

385 Probabilistic analysis of the results of incremental dynamic analysis provided data to generate

386 fragility curves that can be used as analytical tools for seismic vulnerability assessment. Fragility

387 curves were developed and presented for six 1965 buildings, three in each location, for

388 immediate occupancy and collapse prevention as performance levels. The fragility curves are

389 compared with those generated in an earlier phase of the same investigation by the authors. The

390 results indicate that the frame buildings in Vancouver showed very high probability of collapse

391 when investigated under the 2010 NBCC seismic hazard prior to reaching the life safety limit of

$392 \%$ of inter-storey drift. The frame buildings in Ottawa showed very small probabilities (on

393 average $6 \%$ ) of exceeding the collapse prevention limit under the same level of seismic hazard.

394 All the buildings experienced inelastic shear deformations in their first storey columns with the

395 10-storey building experiencing shear failure. The beams remained elastic in shear but developed

396 flexural hinges. The buildings showed poor performance relative to those designed and analysed

397 earlier on the basis of the ductile design requirements of the 2010 NBCC. The comparisons and

398 the specific probabilities of exceedances for different levels of performance are indicated in the

399 paper. As indicated earlier, the fragility curves were developed for rigidly connected frame

400 elements that do not experience significant softening in beam-column joints. The effect of 
401 potential softening in joints with possible elongation in building period and its effect on spectral 402 acceleration as seismic intensity measure can be accounted for approximately by the user 403 through selecting a longer building period. Other parameters that pertain to potential variability 404 in building materials and construction practices are not included in the fragility analysis and the 405 buildings were assumed to fully conform to the requirements of their design NBCC and the 406 prevailing construction practices of the era.

407 In addition to the fragility based assessment, two other approaches were employed for seismic 408 performance assessment of 1965 buildings; annual frequency of collapse and push-over analysis. 409 Both approached showed agreement with the fragility analysis, indicating similar trends, i.e., 410 significantly poor performance of 1965 buildings relative to 2010 buildings, both for western 411 Canada (as represented by Vancouver buildings) and eastern Canada (as represented by Ottawa 412 Buildings). It may be concluded that the fragility curves generated provide useful analytical tools 413 for pre-1975 reinforced concrete frame buildings in Canada having regular structural layouts 414 within a wide range of fundamental periods.

\section{References}

420 ACI. 2013. Guide for testing reinforced concrete structural elements under slowly applied simulated seismic loads. ACI committee 374. American Concrete Institute. ACI 374.2R-13 
Al Mamun, A. and Saatcioglu, M. 2017. Seismic fragility curves for reinforced concrete frame buildings in Canada designed after 1985. Canadian Journal of Civil Engineering. Volume 44, Number 7, page 558-568.

424 ASCE. 2014. Seismic evaluation and retrofit of existing buildings. American Society of Civil Engineers. ASCE/SEI 41-13.

Adams, J. and Halchuk, S. 2003. Fourth generation seismic hazard maps of Canada: Values for over 650 Canadian localities intended for the 2005 National Building Code of Canada. Geological Survey of Canada. Open file 4459.

Atkinson, G.M. 2009. Earthquake time histories compatible with the 2005 National building code of Canada uniform hard spectrum. Canadian Journal of Civil Engineering. Volume 36, Number 6, June 2009.

Bonacci, J. and Pantazopoulou, S. Parametric investigation of joint mechanics. ACI Structural Journal, V. 90, N0.1, 1993, Pages 61-71.

Bradley, B. and Dhakal, R. 2008. Error estimation of closed-form solution for annual rate of structural collapse. Earthquake Engineering \& Structural Dynamics. Volume 37, Issue 15. Pages 1721-1737.

Bilgin, Huseyin. 2013. Fragility-based assessment of public buildings in Turkey. Engineering Structures no.

$$
56: 1283-1294 .
$$

Buratti, N., Ferracuti, B. and Savoia, M. 2010. Response surface with random factors for seismic fragility of reinforced concrete frames. Structural Safety. Volume 32, Issue 1, Pages 42-51.

Huseyin Bilgin. 2013. Fragility-based assessment of public buildings in Turkey. Engineering Structures. Volume 56, Pages 1283-1294.

CSA. 1973. Design of concrete structures. CSA standards update service. Canadian Standards Association. CSA A23.3-1973. Missisuaga, ON.

CSA. 1984. Design of concrete structures. CSA standards update service. Canadian Standards Association. CSA A23.3-1984. Missisuaga, ON.

CSI. 2008. ETABS. Nonlinear Version 9.5.0. Computers and Structures, Inc. Berkeley, CA.

447 Ellingwood, B.R., Celik, O.C., and Kinali, K. 2007. Fragility assessment of building structural systems in MidAmerica. Earthquake Engineering and Structural Dynamics. 36(13):1935-1952. doi: 10.1002/eqe.693

FEMA. 2000a. Prestandard and commentary for the seismic rehabilitation of buildings. Federal Emergency Management Agency. FEMA 356. Washington, D.C.

FEMA. 2000b. Recommended seismic design criteria for new steel moment-frame buildings. SAC Joint Venture.

$$
\text { Federal Emergency Management Agency. FEMA 350. Washington, D.C. }
$$


453 Goulet, C.A., Haselton,C.B.,Reiser,J.M., Beck, J.L., Deierlein, G.G., Porter, K.A. and Stewart, J.P. 2007. Evaluation 454 of the seismic performance of a code-conforming reinforced-concrete frame building-from seismic hazard to 455 collapse safety and economic losses. Earthquake Engineering \& Structural Dynamics. Volume 36, Issue 23. 456 Pages 1973-1997.

457 Haselton, Curt B. 2006. Assessing seismic collapse safety of modern reinforced concrete moment frame buildings. Stanford University. Ph.D. Thesis.

459 Ibarra, L.F. and Krawinkler, H. 2005. Global collapse of frame structures under seismic excitations. Department of 460 Civil and Environmental Engineering. Stanford University. Final report on PEER project 3192002 . Report no. $461 \quad 152$.

462 Jeong, S. H., and Elnashai, A.S. 2007. Fragility relationships for torsionally-imbalanced buildings using three463 dimensional damage characterization. Engineering structures. Volume 29, Issue 9, Pages 2172-2182.

464 Lupoi, G., Franchin, P., Lupoi, P and Pinto, P. 2006. Seismic fragility analysis of structural systems. Engineering 465 Mechanics. Vol 132, Issue 4, Page 385-395.

466 Mitchell, D., Paultre, P., Tinawi, R., Saatcioglu, M., Tremblay, R., Elwood, K., Adams, J., and DeVall, R. 2010.

467 Evolution of seismic design provisions in the national building code of Canada. Canadian Journal of Civil 468 Engineering. Volume 37, Issue 9, Pages 1157-1170

469 NRCC. 1941. National building code of Canada 1941. Associate Committee on the National Building Code. $470 \quad$ National Research Council of Canada, Ottawa, ON.

471 NRCC. 1953. National building code of Canada 1953. Associate Committee on the National Building Code. 472 National Research Council of Canada, Ottawa, ON.

473 NRCC. 1965. National building code of Canada 1965. Associate Committee on the National Building Code. $474 \quad$ National Research Council of Canada, Ottawa, ON.

475 NRCC. 1970. National building code of Canada 1970. Associate Committee on the National Building Code. 476 National Research Council of Canada, Ottawa, ON.

477 NRCC. 1975. National building code of Canada 1975. Associate Committee on the National Building Code. 478 National Research Council of Canada, Ottawa, ON.

479 NRCC. 1977. National building code of Canada 1977. Associate Committee on the National Building Code. 480 National Research Council of Canada, Ottawa, ON.

481 NRCC. 1980. National building code of Canada 1980. Associate Committee on the National Building Code. 482 National Research Council of Canada, Ottawa, ON.

483 NRCC. 1985. National building code of Canada 1985. Associate Committee on the National Building Code. 484 National Research Council of Canada, Ottawa, ON. 
NRCC. 1990. National building code of Canada 1990. Associate Committee on the National Building Code. National Research Council of Canada, Ottawa, ON.

NRCC. 1995. National building code of Canada 1995. Associate Committee on the National Building Code. National Research Council of Canada, Ottawa, ON.

NRCC. 2005. National building code of Canada 2005. Associate Committee on the National Building Code. National Research Council of Canada, Ottawa, ON.

NRCC. 2010. National building code of Canada 2010. Associate Committee on the National Building Code. National Research Council of Canada, Ottawa, ON.

NRCC. 2015. National building code of Canada 2015. Associate Committee on the National Building Code. National Research Council of Canada, Ottawa, ON.

Ozcebe, G., Saatcioglu, M. 1987. Confinement of concrete columns for seismic loading. ACI Structural Journal. Volume 84, Issue 4, Pages 308-315.

Ozcebe, G., Saatcioglu, M. 1989. Hysteretic shear model for reinforced concrete members. Journal of the Structural Engineering, ASCE. Volume 115, Issue 1, pp. 132-148.

Rajeev, P., and Tesfamariam, S. 2012. Seismic fragilities for reinforced concrete buildings with consideration of irregularities. Structural Safety. https://doi.org/10.1016/j.strusafe.2012.06.001

Ramamoorthy, S. K., Gardoni, P. and Bracci, J. M. 2008. Seismic fragility and confidence bounds for gravity load designed reinforced concrete frames of varying height. Journal of Structural Engineering. Volume 134, Issue 4, Pages 639-650.

Vamvatsikos, D., and Cornell, C.A. 2004. Applied incremental dynamic analysis. Earthquake Spectra. Vol 20, No. 2, Page 523-553, May 2004.

Ventura, C., Finn, L., Onur, T., Blanquera, A., and Rezai, M. 2005. Regional seismic risk in British Columbiaclassification of buildings and development of damage probability functions. Canadian Journal of Civil

\section{LIST OF FIGURES}

511 Fig. 1. Evolution of NBCC seismic design base shears over the years for (a) 2-storey, (b) 5storey and (c) 10-storey reinforced concrete frame buildings.

513 Fig. 2. Schematic diagram of (a) 5-storey building model in ETABS and (b) reinforced concrete frame elements in PERFORM-3D analytical model. 
515 Fig. 3. Moment-rotation envelope used to develop analytical model in PERFORM-3D

516 Fig. 4. Evaluation of (a) shear and (b) flexural EDF for 1965 NBCC structures from test performed by Ozcebe and Saatcioglu (1987).

518 Fig. 5. Fragility responses of (a) 2-storey, (b) 5-storey, (c) 10-storey buildings in Ottawa; and (c) 2-storey, (d) 5-storey, (e) 10-storey buildings in Vancouver.

Fig. 6. Graphical representation to calculate annual probability of exceedance $(v)$ for the 2-storey Vancouver building designed for 2010 NBCC.

524 Fig. 8. Push-over curves for 2-, 5- and 10-storey structures.

525 Fig. 9. Idealized force-deformation relationship based on FEMA 356 for the 2-storey Vancouver building designed for 2010 NBCC.

527 Fig. 10. Effect of (a) global ductility ratio and (b) over-strength ratio on mean annual collapse frequency in Ottawa.

Fig. 11. Effect of (a) global ductility ratio and (b) over-strength ratio on mean annual collapse frequency in Vancouver. 
Table 1. Design details for columns and beams of 1965 and 2010 buildings

\begin{tabular}{|c|c|c|c|c|c|c|c|c|c|c|c|c|c|c|}
\hline & \multirow{2}{*}{\multicolumn{3}{|c|}{$\begin{array}{c}2 \text { Storey (40MPa) } \\
2010 \\
\end{array}$}} & \multirow{2}{*}{\multicolumn{2}{|c|}{$\begin{array}{c}2 \text { Storey (30MPa) } \\
1965 \\
\end{array}$}} & \multirow{2}{*}{\multicolumn{2}{|c|}{$\begin{array}{c}5 \text { Storey (30MPa) } \\
2010 \\
\end{array}$}} & \multirow{2}{*}{\multicolumn{2}{|c|}{$\begin{array}{c}5 \text { Storey (30MPa) } \\
1965 \\
\end{array}$}} & \multicolumn{3}{|c|}{10 Storey (40MPa) } & \multirow{2}{*}{\multicolumn{2}{|c|}{$\begin{array}{c}\text { 10 Storey (40MPa) } \\
1965 \\
\end{array}$}} \\
\hline & & & & & & & & & & & $\begin{array}{c}2010 \\
\text { (Ottawa) }\end{array}$ & 2010 (Vanc.) & & \\
\hline & Size & \multicolumn{2}{|c|}{ Rebar } & Size & Rebar & Size & Rebar & Size & Rebar & Size & Rebar & Rebar & Size & Rebar \\
\hline $\begin{array}{l}\text { Corner Column } \\
1 \text {-Top } \\
\end{array}$ & $300 \times 300$ & \multicolumn{2}{|c|}{$8-20 \mathrm{M}$} & $300 \times 300$ & $\begin{array}{c}4-25 \mathrm{M}+4- \\
20 \mathrm{M} \\
\end{array}$ & $300 \times 300$ & $8-20 \mathrm{M}$ & $300 \times 300$ & $\begin{array}{c}4-25 \mathrm{M}+4- \\
15 \mathrm{M} \\
\end{array}$ & $350 \times 350$ & $\begin{array}{c}4-25 \mathrm{M}+4- \\
15 \mathrm{M} \\
\end{array}$ & $4-25 \mathrm{M}+4-15 \mathrm{M}$ & $350 \times 350$ & 8-20M \\
\hline Ext Column 1-2 & $300 \times 300$ & \multicolumn{2}{|c|}{$4-30 \mathrm{M}$} & $300 \times 300$ & $8-25 \mathrm{M}$ & $300 \times 300$ & $4-30 \mathrm{M}$ & $325 \times 325$ & $8-25 \mathrm{M}$ & $350 \times 350$ & $16-20 \mathrm{M}$ & $4-30 \mathrm{M}+8-20 \mathrm{M}$ & $400 \times 400$ & $8-25 \mathrm{M}$ \\
\hline $\begin{array}{l}\text { Ext Column 3- } \\
\text { Top }\end{array}$ & - & \multicolumn{2}{|c|}{ - } & - & - & $300 \times 300$ & $4-25 \mathrm{M}$ & $325 \times 325$ & $\begin{array}{c}4-25 \mathrm{M}+4- \\
20 \mathrm{M} \\
\end{array}$ & $350 \times 350$ & $\begin{array}{c}4-25 \mathrm{M}+4- \\
15 \mathrm{M}\end{array}$ & $8-25 \mathrm{M}$ & $400 \times 400$ & $\begin{array}{c}4-25 \mathrm{M}+4- \\
20 \mathrm{M}\end{array}$ \\
\hline $\begin{array}{l}\text { Int-1 Column } \\
1-2\end{array}$ & $325 \times 325$ & \multicolumn{2}{|c|}{$4-20 M+4-15 M$} & $300 \times 300$ & $8-15 \mathrm{M}$ & $450 \times 450$ & $12-25 \mathrm{M}$ & $400 \times 400$ & 8-30M & $500 \times 500$ & $\begin{array}{c}12- \\
30 \mathrm{M}+8- \\
20 \mathrm{M} \\
\end{array}$ & $\begin{array}{c}12-30 \mathrm{M}+8- \\
25 \mathrm{M}\end{array}$ & $500 \times 500$ & $\begin{array}{c}12-25 \mathrm{M}+4- \\
20 \mathrm{M}\end{array}$ \\
\hline $\begin{array}{l}\text { Int-1 Column } \\
3-5\end{array}$ & - & \multicolumn{2}{|c|}{ - } & - & - & $450 \times 450$ & $\begin{array}{c}4-25 \mathrm{M}+4- \\
20 \mathrm{M} \\
\end{array}$ & $400 \times 400$ & $\begin{array}{c}4-25 \mathrm{M}+4- \\
15 \mathrm{M} \\
\end{array}$ & $500 \times 500$ & $\begin{array}{c}8-25 \mathrm{M}+8- \\
20 \mathrm{M}\end{array}$ & $8-30 \mathrm{M}+8-25 \mathrm{M}$ & $500 \times 500$ & $8-25 \mathrm{M}$ \\
\hline $\begin{array}{l}\text { Int-1 Column } \\
6-10\end{array}$ & - & \multicolumn{2}{|c|}{ - } & - & - & & - & & - & $500 \times 500$ & $\begin{array}{c}4-25 \mathrm{M}+4- \\
15 \mathrm{M}\end{array}$ & $4-25 \mathrm{M}+4-20 \mathrm{M}$ & $500 \times 500$ & $\begin{array}{c}4-25 \mathrm{M}+4- \\
15 \mathrm{M} \\
\end{array}$ \\
\hline $\begin{array}{l}\text { Int-2 Column } \\
1-2\end{array}$ & $325 \times 325$ & \multicolumn{2}{|c|}{$4-20 M+4-15 M$} & $300 \times 300$ & $8-15 \mathrm{M}$ & $450 \times 450$ & $\begin{array}{l}4-30 \mathrm{M}+8- \\
20 \mathrm{M}\end{array}$ & $400 \times 400$ & $\begin{array}{c}4-30 \mathrm{M}+4- \\
25 \mathrm{M}\end{array}$ & $500 \times 500$ & $\begin{array}{c}12- \\
30 \mathrm{M}+8- \\
20 \mathrm{M} \\
\end{array}$ & $\begin{array}{c}12-30 \mathrm{M}+8- \\
20 \mathrm{M}\end{array}$ & $500 \times 500$ & $\begin{array}{c}8-25 \mathrm{M}+8- \\
20 \mathrm{M}\end{array}$ \\
\hline $\begin{array}{l}\text { Int-2 Column } \\
3-5\end{array}$ & - & \multicolumn{2}{|c|}{-} & - & - & $450 \times 450$ & $4-30 \mathrm{M}$ & $400 \times 400$ & $8-20 \mathrm{M}$ & $500 \times 500$ & $\begin{array}{c}8-25 \mathrm{M}+8- \\
15 \mathrm{M} \\
\end{array}$ & $\begin{array}{c}12-25 \mathrm{M}+8- \\
20 \mathrm{M} \\
\end{array}$ & $500 \times 500$ & $\begin{array}{c}4-25 \mathrm{M}+8- \\
15 \mathrm{M} \\
\end{array}$ \\
\hline $\begin{array}{l}\text { Int-2 Column } \\
6-10\end{array}$ & - & \multicolumn{2}{|c|}{ - } & - & - & & - & & - & $500 \times 500$ & $\begin{array}{c}4-25 \mathrm{M}+4- \\
15 \mathrm{M} \\
\end{array}$ & $4-25 \mathrm{M}+4-20 \mathrm{M}$ & $500 \times 500$ & $\begin{array}{c}4-25 \mathrm{M}+4- \\
15 \mathrm{M} \\
\end{array}$ \\
\hline $\begin{array}{l}\text { Int-3 Column } \\
1-2\end{array}$ & $325 \times 325$ & \multicolumn{2}{|c|}{$4-20 \mathrm{M}+4-15 \mathrm{M}$} & $300 \times 300$ & $4-20 \mathrm{M}$ & $450 \times 450$ & $\begin{array}{c}4-25 \mathrm{M}+8- \\
20 \mathrm{M}\end{array}$ & $400 \times 400$ & $8-25 \mathrm{M}$ & $500 \times 500$ & $\begin{array}{c}8-30 \mathrm{M}+8- \\
25 \mathrm{M}\end{array}$ & $\begin{array}{c}12-30 \mathrm{M}+8- \\
20 \mathrm{M}\end{array}$ & $500 \times 500$ & $12-25 \mathrm{M}$ \\
\hline $\begin{array}{l}\text { Int-3 Column } \\
3-5 \\
\end{array}$ & - & \multicolumn{2}{|c|}{ - } & - & - & $450 \times 450$ & $8-20 \mathrm{M}$ & $400 \times 400$ & $8-20 \mathrm{M}$ & $500 \times 500$ & $\begin{array}{c}4-25 \mathrm{M}+8- \\
20 \mathrm{M}\end{array}$ & $\begin{array}{c}12-25 \mathrm{M}+4- \\
20 \mathrm{M} \\
\end{array}$ & $500 \times 500$ & $\begin{array}{c}4-25 \mathrm{M}+4- \\
15 \mathrm{M} \\
\end{array}$ \\
\hline $\begin{array}{l}\text { Int-3 Column } \\
6-10\end{array}$ & - & \multicolumn{2}{|c|}{ - } & - & - & & - & & - & $500 \times 500$ & $\begin{array}{c}4-25 \mathrm{M}+4- \\
15 \mathrm{M} \\
\end{array}$ & $4-25 \mathrm{M}+4-20 \mathrm{M}$ & $500 \times 500$ & $\begin{array}{c}4-25 \mathrm{M}+4- \\
15 \mathrm{M} \\
\end{array}$ \\
\hline Ext Beam Top & $300 \times 500$ & \multicolumn{2}{|c|}{ 3-20M } & $300 \times 500$ & 4-20M & $300 \times 500$ & 3-20M & $300 \times 500$ & $4-20 \mathrm{M}$ & $350 \times 500$ & 3-20M & $3-20 \mathrm{M}$ & $350 \times 500$ & $2-25 \mathrm{M}$ \\
\hline \multirow[t]{2}{*}{$\begin{array}{l}\text { Ext Beam } \\
\text { 3ottom }\end{array}$} & $300 \times 500$ & \multicolumn{2}{|c|}{$2-20 \mathrm{M}$} & $300 \times 500$ & $2-20 \mathrm{M}$ & $300 \times 500$ & $2-20 \mathrm{M}$ & $300 \times 500$ & $2-20 \mathrm{M}$ & $350 \times 500$ & $2-20 \mathrm{M}$ & $2-20 \mathrm{M}$ & $350 \times 500$ & $2-20 \mathrm{M}$ \\
\hline & & Ottawa & Vanc. & & & & & & & & & & & \\
\hline $\begin{array}{l}\text { Int Beam 1-5 } \\
\text { Top }\end{array}$ & $300 \times 500$ & $4-20 \mathrm{M}$ & $4-20 \mathrm{M}$ & $300 \times 500$ & $3-25 \mathrm{M}$ & $300 \times 500$ & $3-25 \mathrm{M}$ & $300 \times 500$ & $3-25 \mathrm{M}$ & $350 \times 500$ & $4-25 \mathrm{M}$ & $4-25 \mathrm{M}$ & $350 \times 500$ & $5-25 \mathrm{M}$ \\
\hline $\begin{array}{l}\text { Int Beam 1-5 } \\
\text { Bottom }\end{array}$ & $300 \times 500$ & 3-20M & 4-20M & $300 \times 500$ & 3-15M & $300 \times 500$ & $2-25 \mathrm{M}$ & $300 \times 500$ & $3-20 \mathrm{M}$ & $350 \times 500$ & $2-25 \mathrm{M}$ & $4-25 \mathrm{M}$ & $350 \times 500$ & $4-20 \mathrm{M}$ \\
\hline $\begin{array}{l}\text { Int Beam 6-10 } \\
\text { Top }\end{array}$ & - & - & - & - & - & - & - & - & - & $350 \times 500$ & $3-25 \mathrm{M}$ & $3-25 \mathrm{M}$ & $350 \times 500$ & $4-25 \mathrm{M}$ \\
\hline $\begin{array}{l}\text { Int Beam 6-10 } \\
\text { Bottom }\end{array}$ & - & - & - & - & - & - & - & - & - & $350 \times 500$ & $3-20 \mathrm{M}$ & $3-25 \mathrm{M}$ & $350 \times 500$ & $2-25 \mathrm{M}$ \\
\hline
\end{tabular}


Table 2. Comparisons of vulnerability assessment for 1965 and 2010 buildings

\begin{tabular}{|c|c|c|c|c|c|c|c|c|c|c|c|c|c|c|c|c|c|c|c|c|}
\hline \multirow{2}{*}{$\begin{array}{l}0 \\
0 \\
0 \\
\tilde{50} \\
\tilde{0} \\
0 \\
0\end{array}$} & \multirow{2}{*}{ Building } & \multirow{2}{*}{ Region } & \multirow{2}{*}{$\mathrm{T}_{\mathrm{e}}$} & \multirow{2}{*}{$\mathrm{T}_{\mathrm{d}}$} & \multirow{2}{*}{$\mathrm{S}_{\mathrm{a}}\left(\mathrm{T}_{\mathrm{e}}\right)$} & \multirow{2}{*}{$\mathrm{S}_{\mathrm{a}}\left(\mathrm{T}_{\mathrm{d}}\right)$} & \multirow{2}{*}{$\begin{array}{l}\delta_{\max } \\
(\%)\end{array}$} & \multicolumn{3}{|c|}{$\begin{array}{l}\text { Regression } \\
\text { Coefficient }\end{array}$} & \multicolumn{2}{|c|}{$\begin{array}{l}\text { LS Prob. } \\
\text { at } S_{a}\left(T_{e}\right)\end{array}$} & \multirow{2}{*}{$\begin{array}{c}\lambda_{\mathrm{c}} \text { at } \\
\mathrm{S}_{\mathrm{a}}\left(\mathrm{T}_{\mathrm{d}}\right) \\
\mathrm{x} 10^{-04}\end{array}$} & \multirow{2}{*}{$\begin{array}{l}V_{y} \\
\mathrm{Kn}\end{array}$} & \multirow{2}{*}{$\begin{array}{c}\delta_{\mathrm{y}} \\
(\%)\end{array}$} & \multirow{2}{*}{$\begin{array}{l}\mathrm{V}_{\mathrm{d}} \\
\mathrm{Kn}\end{array}$} & \multirow{2}{*}{$\begin{array}{c}\delta_{\mathrm{u}} \\
(\%)\end{array}$} & \multirow{2}{*}{$\begin{array}{l}\mathrm{V}_{\max } \\
\mathrm{Kn}\end{array}$} & \multirow{2}{*}{$\mu$} & \multirow{2}{*}{$\mathrm{R}_{\mathrm{o}}$} \\
\hline & & & & & & & & a & b & $\beta_{D / M}$ & IO & CP & & & & & & & & \\
\hline \multirow{6}{*}{$\begin{array}{l}\text { U } \\
\text { n } \\
\text { Z } \\
\text { 。 }\end{array}$} & 10 -Storey & Ottawa & 2.84 & 1.79 & 0.05 & 0.07 & 2.44 & 16.8 & 1.04 & 0.24 & 26 & 0 & 0 & 2438 & 0.26 & 1843 & 0.74 & 3468 & 2.8 & 1.3 \\
\hline & 5-Storey & Ottawa & 2.04 & 1.06 & 0.05 & 0.13 & 2.94 & 12.4 & 1.02 & 0.21 & 10 & 0 & 3 & 1983 & 0.48 & 1456 & 0.95 & 2738 & 2.0 & 1.4 \\
\hline & 2-Storey & Ottawa & 1.08 & 0.54 & 0.13 & 0.30 & 3.92 & 4.74 & 0.98 & 0.15 & 14 & 0 & 0 & 1667 & 0.54 & 1370 & 1.85 & 2413 & 3.4 & 1.2 \\
\hline & 10-Storey & Vanc. & 2.84 & 1.79 & 0.17 & 0.20 & 3.07 & 11.3 & 1.01 & 0.21 & 95 & 14 & 18 & 3790 & 0.37 & 2936 & 0.86 & 5123 & 2.3 & 1.3 \\
\hline & 5-Storey & Vanc. & 2.04 & 1.06 & 0.17 & 0.32 & 3.91 & 10.3 & 1.00 & 0.18 & 93 & 3 & 54 & 2424 & 0.59 & 1669 & 1.38 & 3031 & 2.4 & 1.5 \\
\hline & 2-Storey & Vanc. & 1.08 & 0.54 & 0.32 & 0.62 & 3.99 & 5.51 & 1.02 & 0.19 & 92 & 2 & 32 & 2296 & 0.78 & 1463 & 2.48 & 2509 & 3.2 & 1.6 \\
\hline \multirow{6}{*}{ 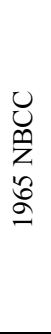 } & 10-Storey & Ottawa & 2.81 & 1.79 & 0.05 & 0.07 & 1.53 & 20.2 & 1.08 & 0.46 & 30 & 8 & 30 & 2475 & 0.27 & 3438 & 0.35 & 2925 & 1.3 & 0.7 \\
\hline & 5-Storey & Ottawa & 2.15 & 1.06 & 0.05 & 0.13 & 1.04 & 12.9 & 0.99 & 0.40 & 11 & 9 & 160 & 1651 & 0.45 & 1770 & 0.60 & 1986 & 1.3 & 0.9 \\
\hline & 2-Storey & Ottawa & 1.14 & 0.54 & 0.13 & 0.30 & 1.80 & 5.48 & 0.99 & 0.38 & 18 & 1 & 82 & 1313 & 0.48 & 1097 & 1.15 & 1909 & 2.4 & 1.2 \\
\hline & 10-Storey & Vanc. & 2.81 & 1.79 & 0.17 & 0.20 & 1.69 & 23.1 & 1.16 & 0.48 & 99 & 88 & 121 & 2234 & 0.25 & 3438 & 0.35 & 2925 & 1.4 & 0.6 \\
\hline & 5-Storey & Vanc. & 2.15 & 1.06 & 0.17 & 0.32 & 1.27 & 13.2 & 1.00 & 0.41 & 97 & 91 & 163 & 1440 & 0.39 & 1770 & 0.60 & 1986 & 1.5 & 0.8 \\
\hline & 2-Storey & Vanc. & 1.14 & 0.54 & 0.31 & 0.62 & 1.48 & 5.26 & 0.98 & 0.38 & 93 & 68 & 222 & 1214 & 0.64 & 1097 & 1.15 & 1909 & 1.8 & 1.1 \\
\hline
\end{tabular}

Note: $T_{d}$ is calculated as $1.5 \times 0.075\left(h_{n}\right)^{3 / 4}$ where $h_{n}$ is height of the structure.

$\delta_{\max }$ is the maximum inter-storey drift corresponding to the collapse prevention (CP) limit state. 

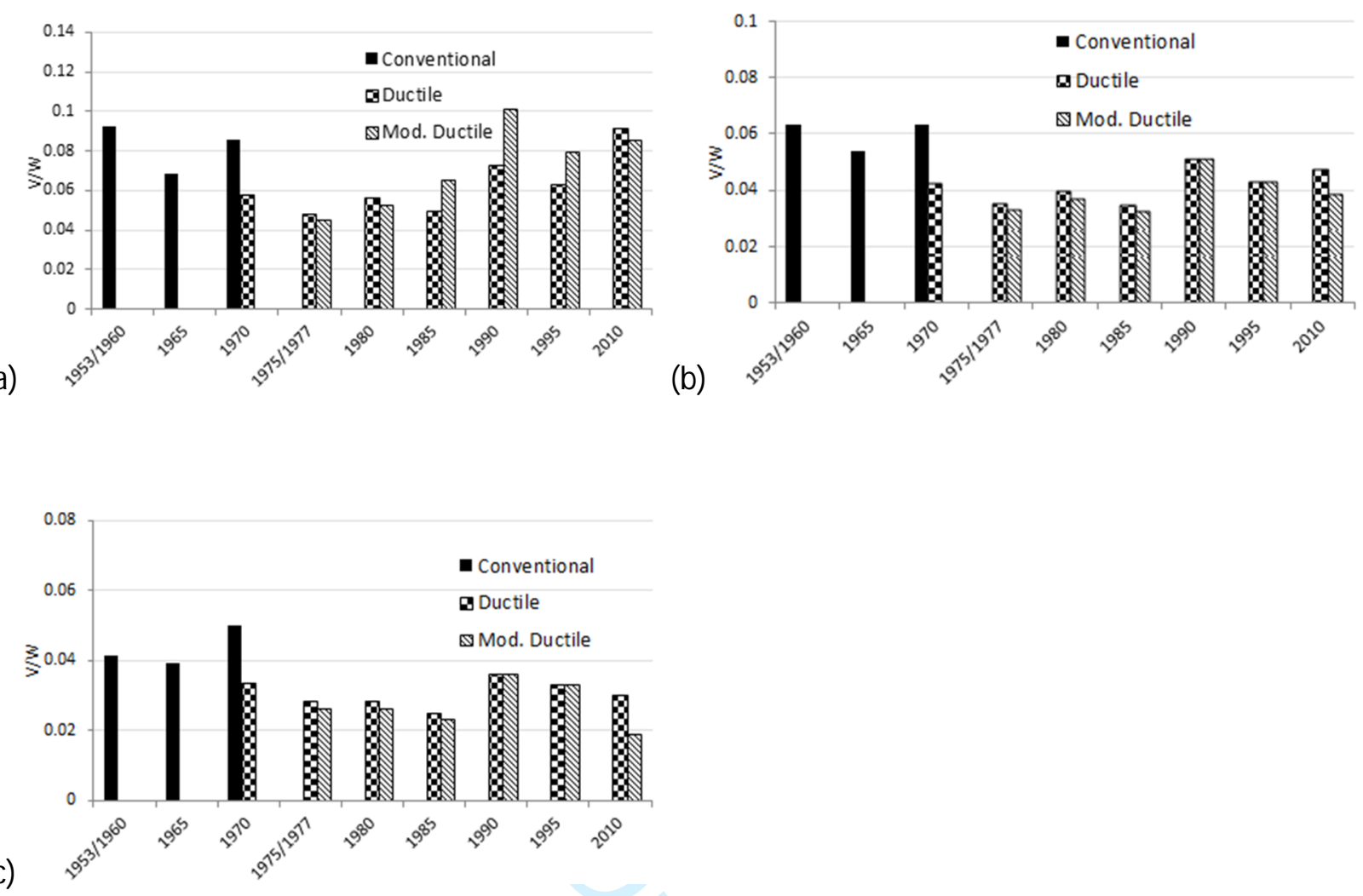

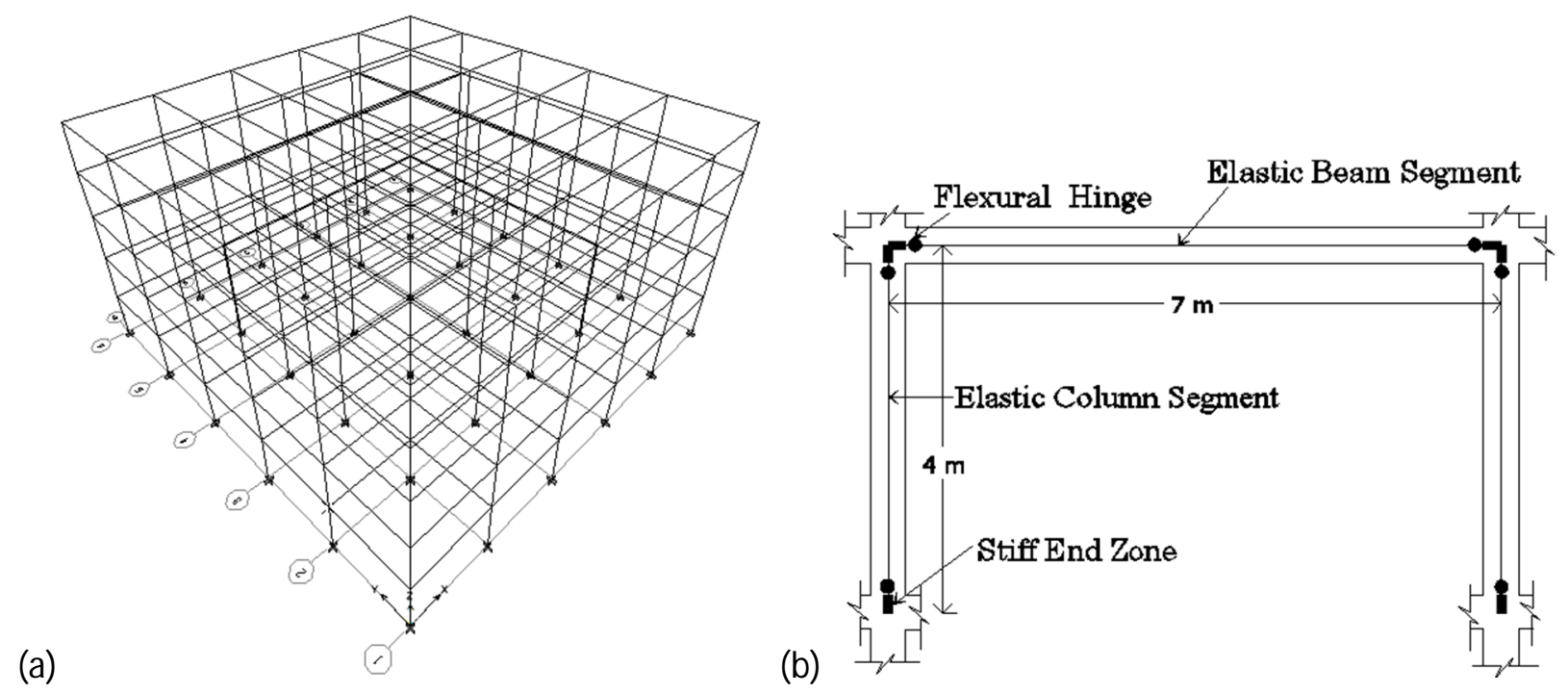


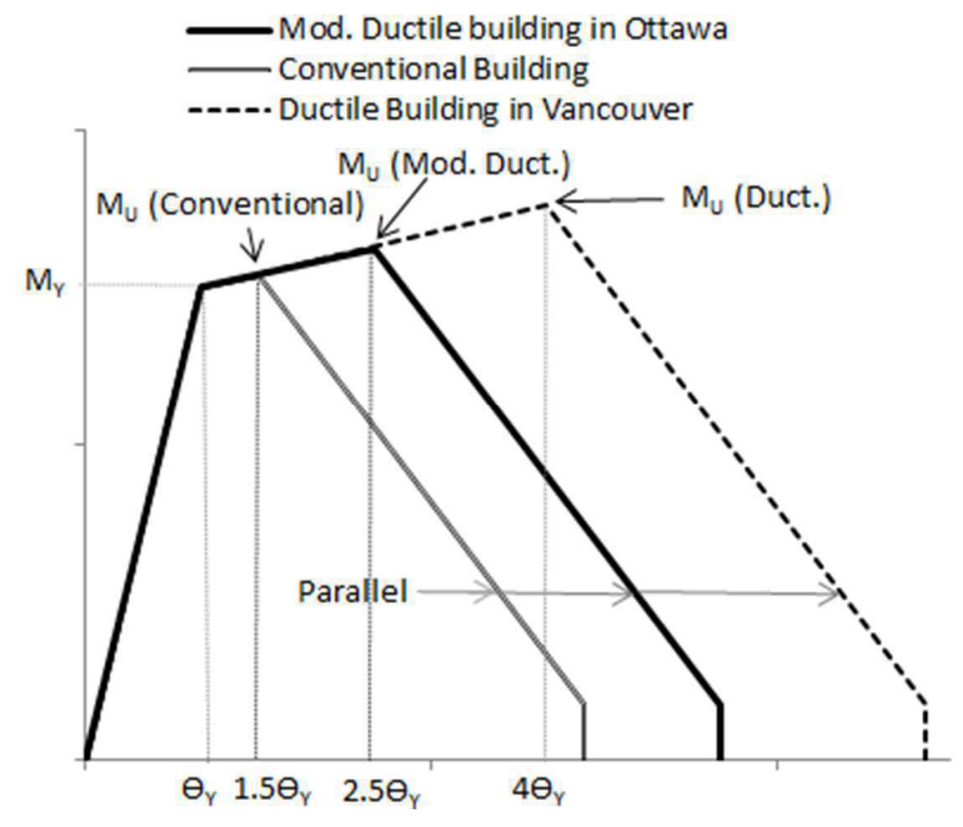



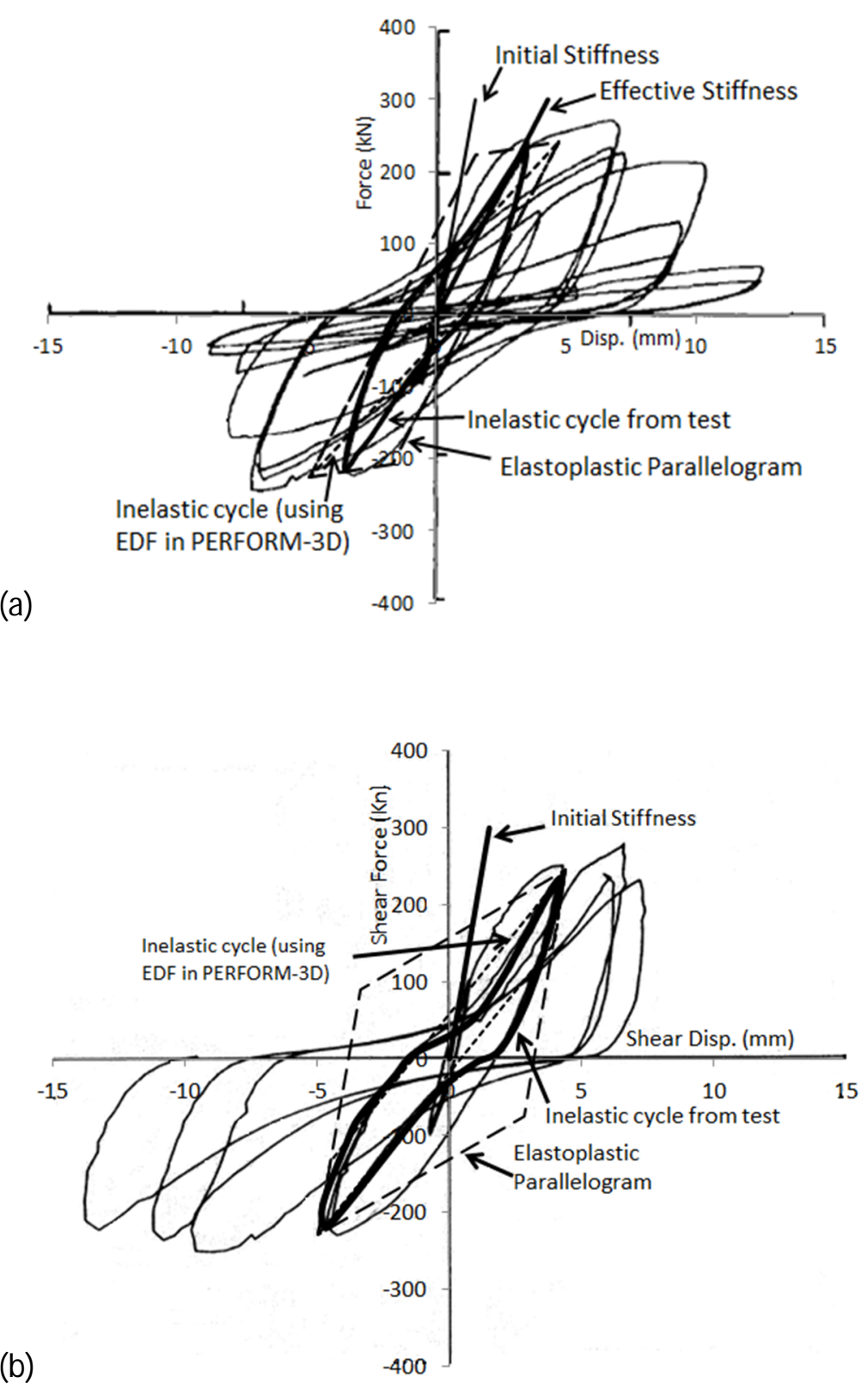
(a)

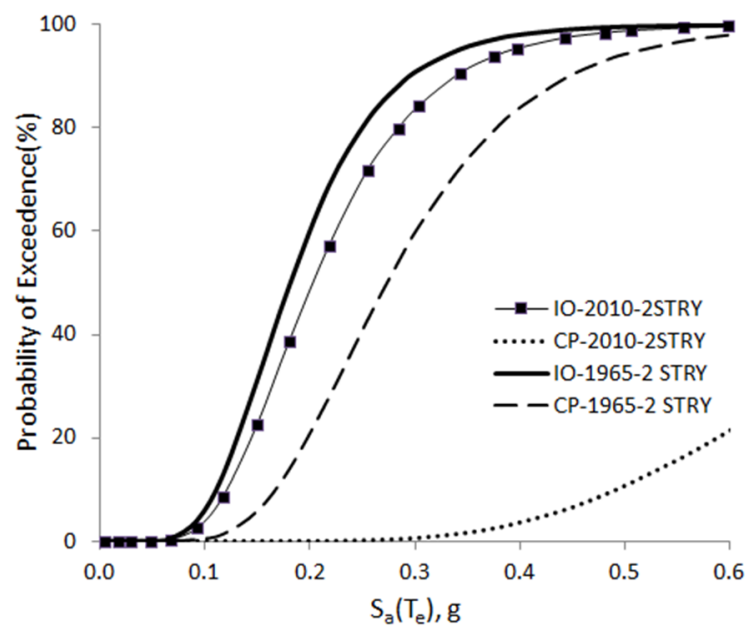

(b)

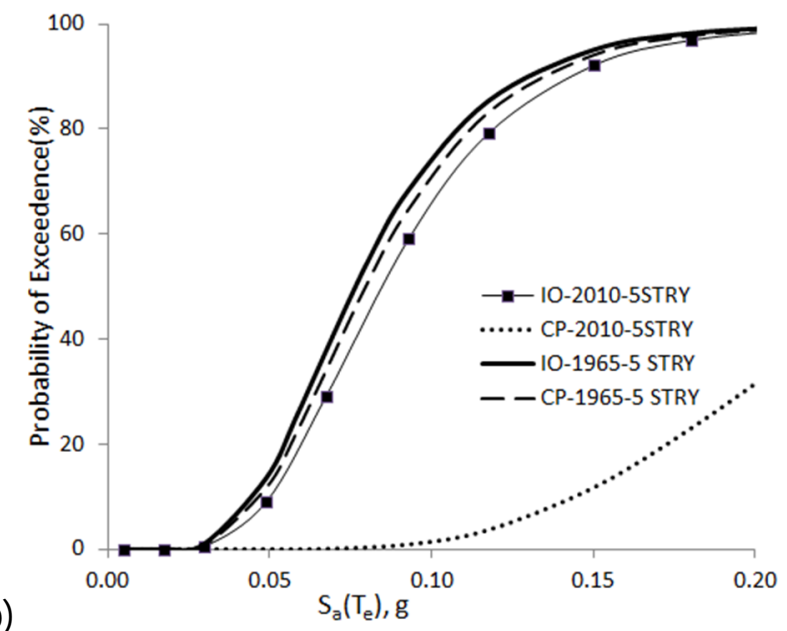

(d)
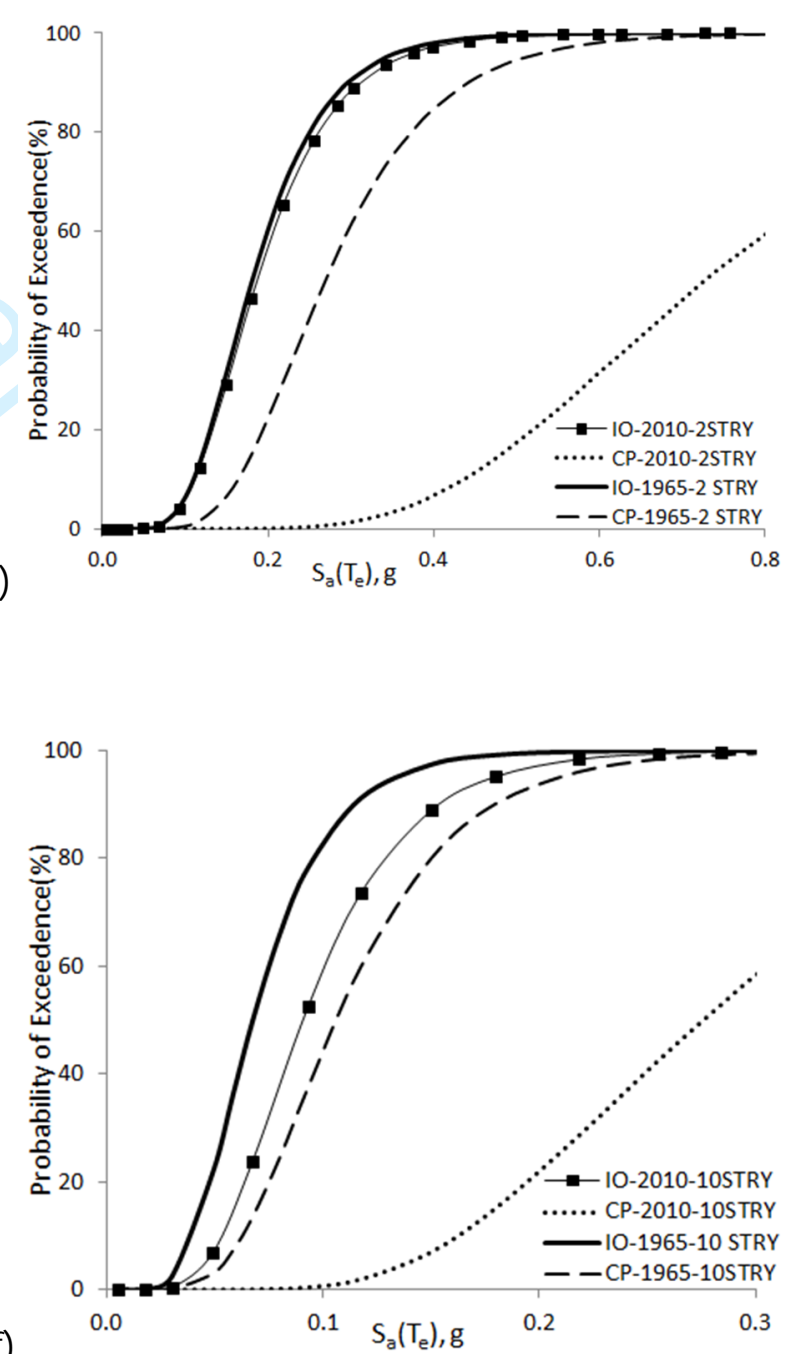

(e)
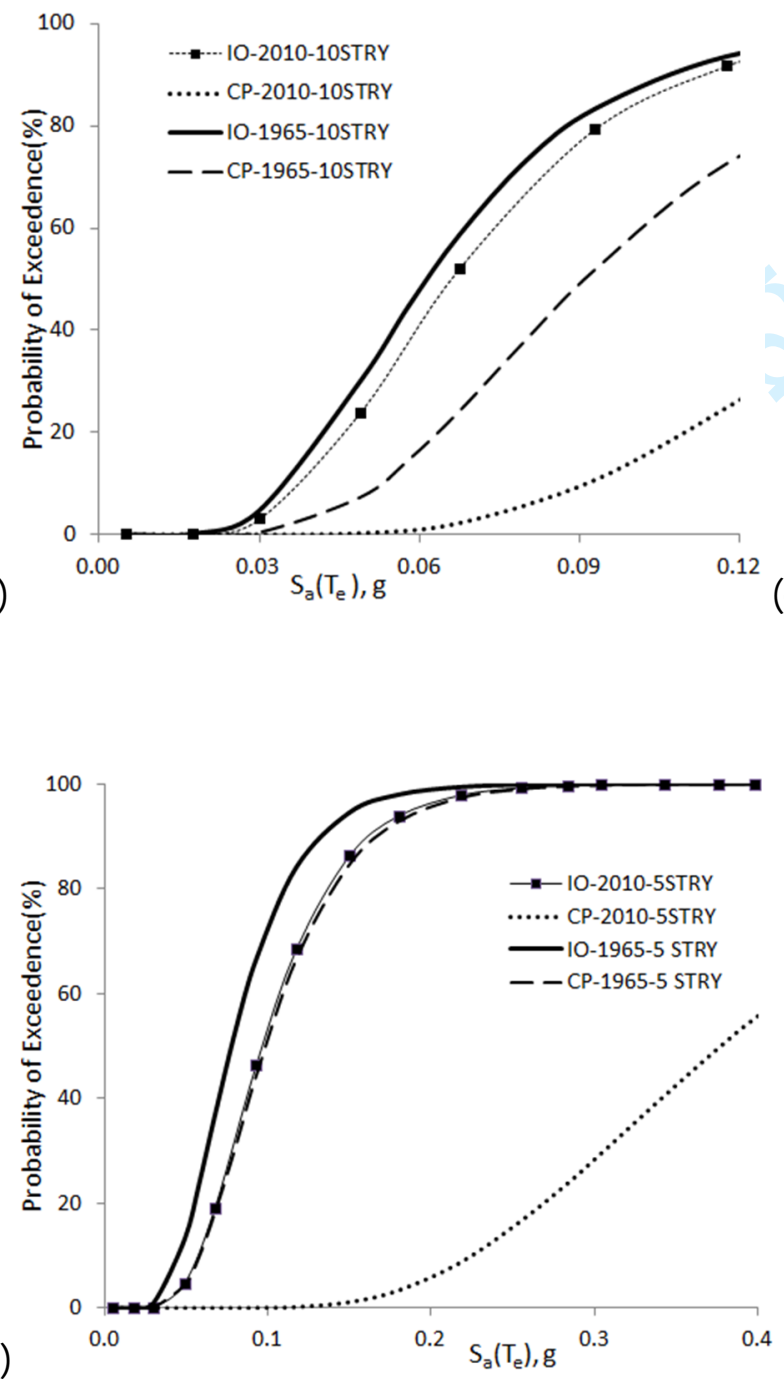

https://mc06.manuscriptcentral.com/cjce-pubs 

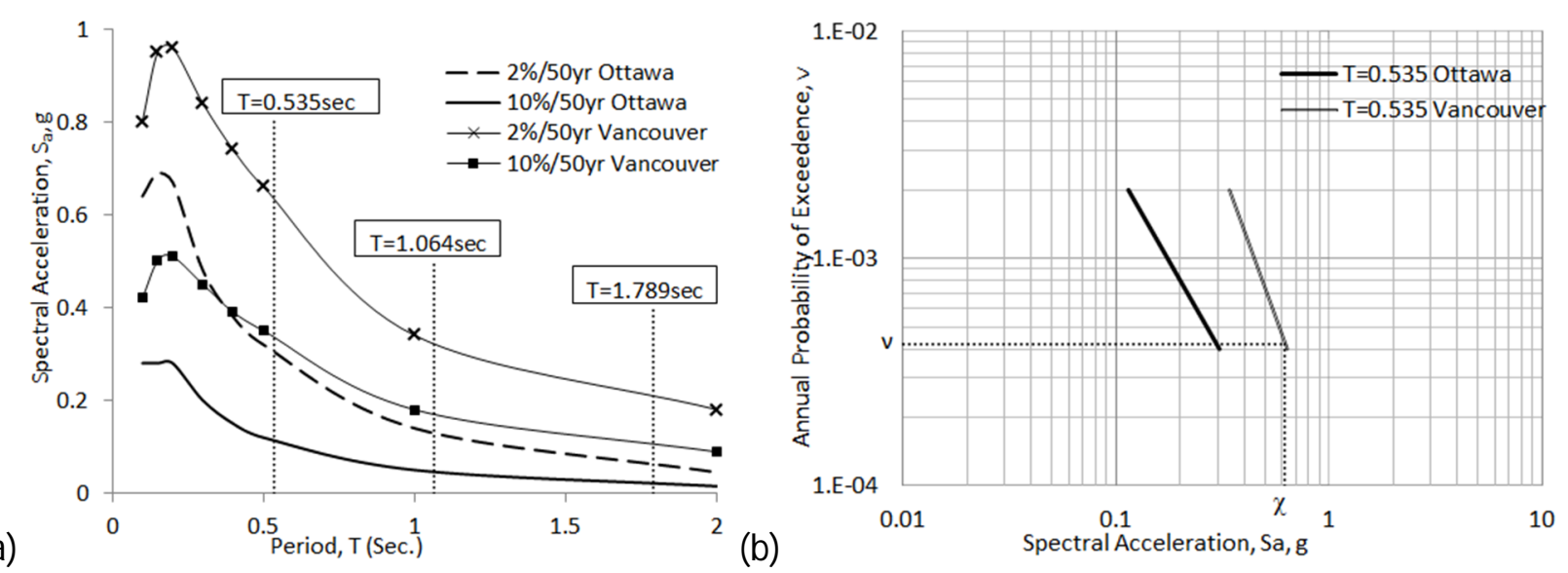

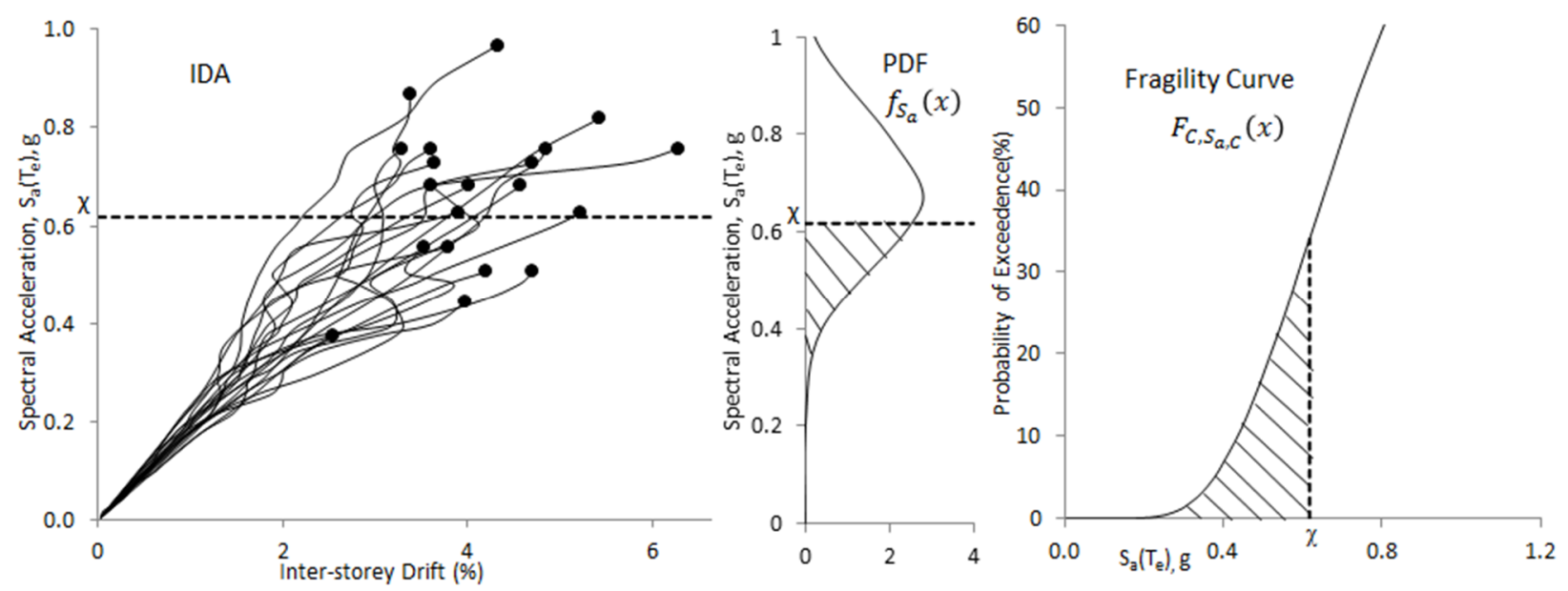

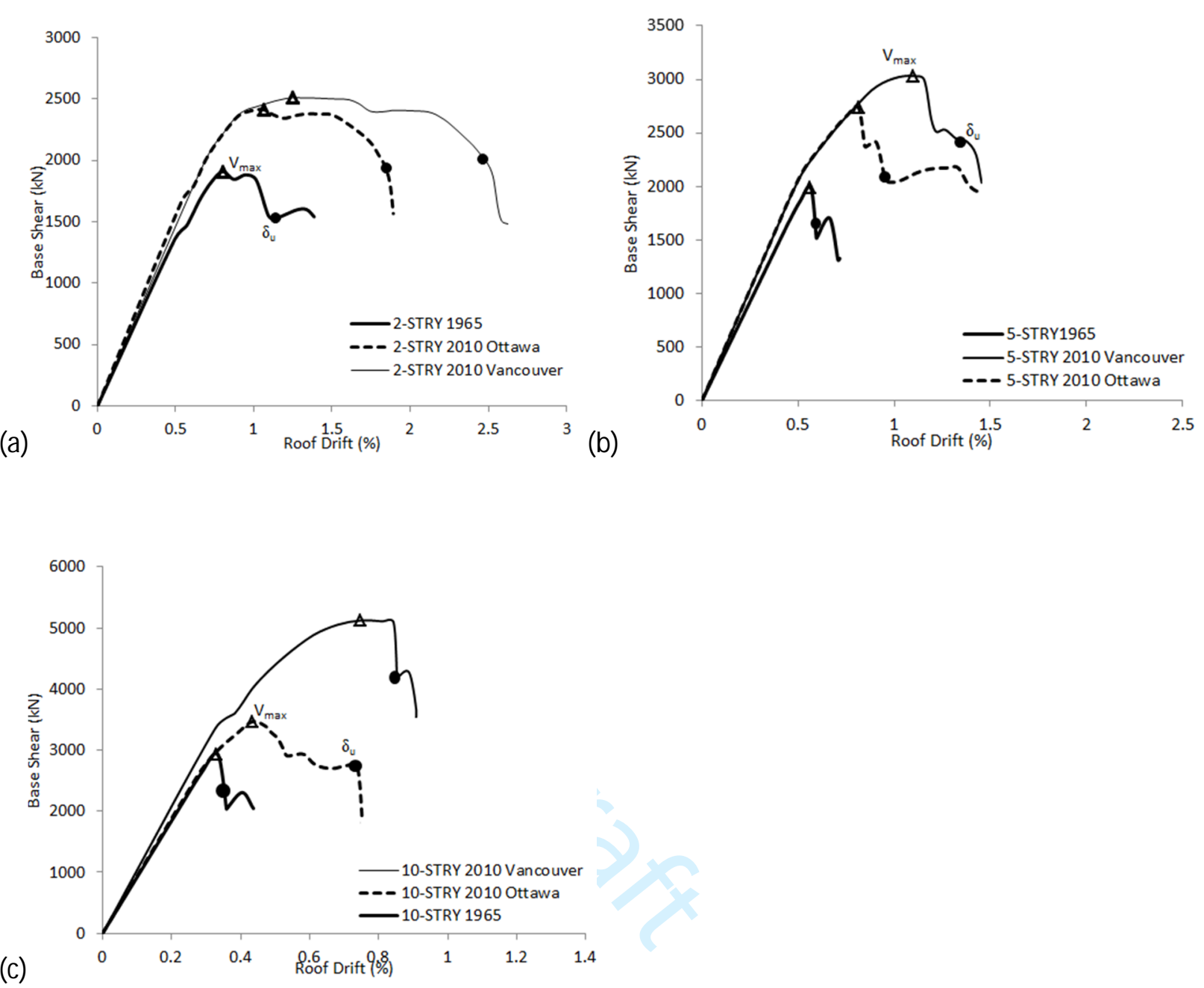


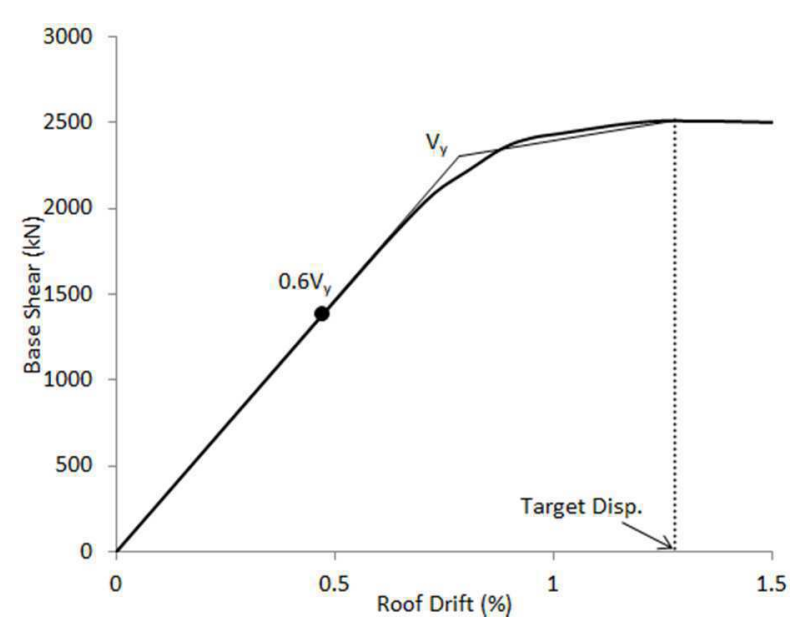




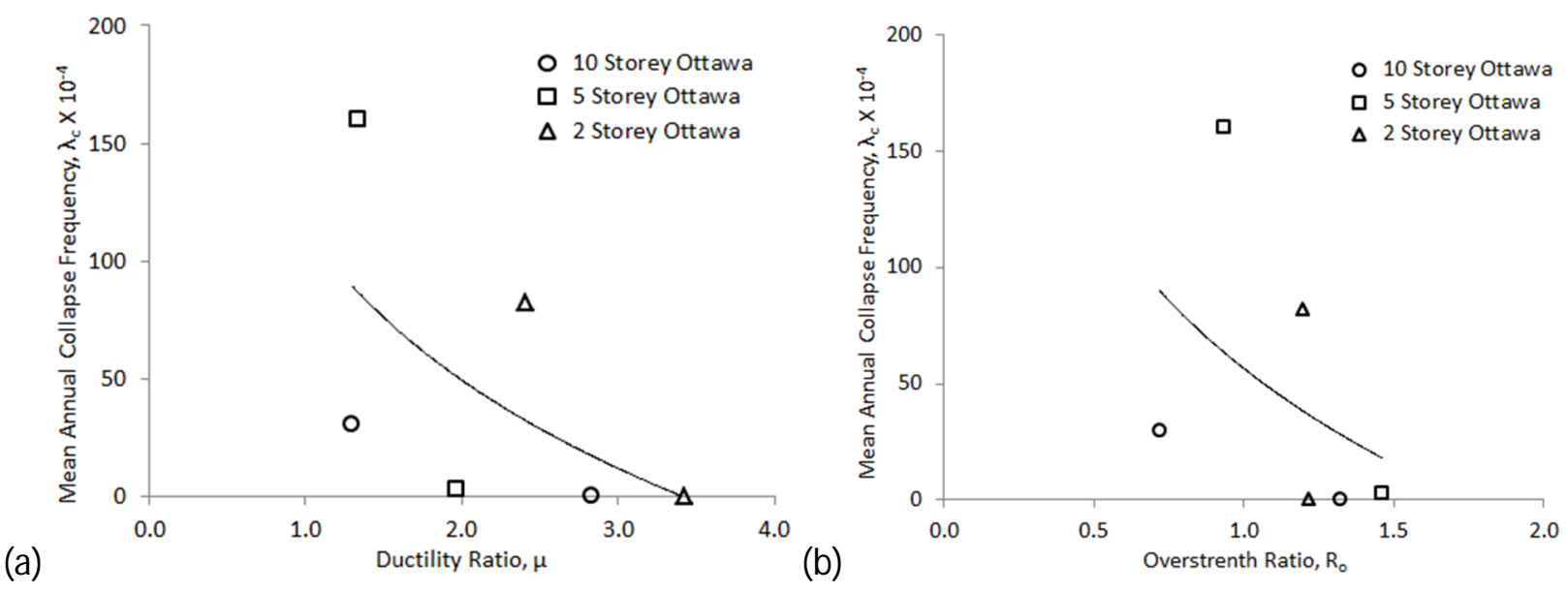




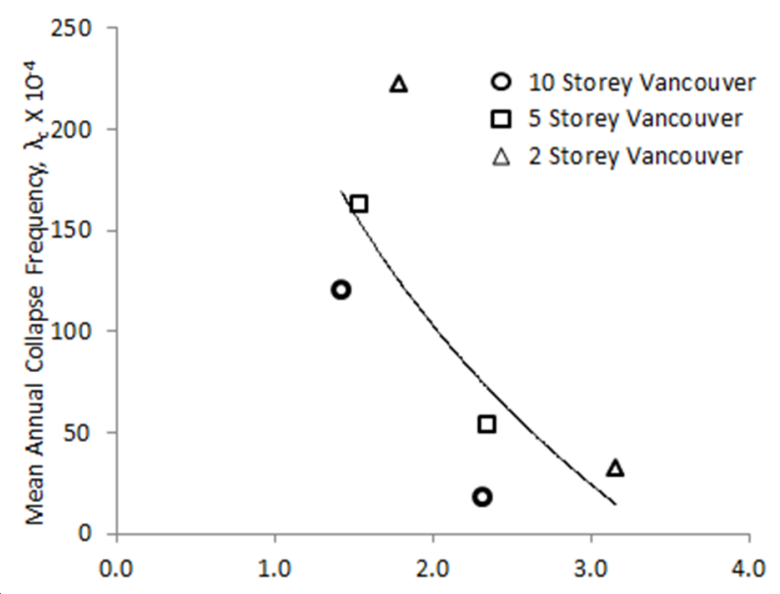

(a)

Ductility Ratio, $\mu$

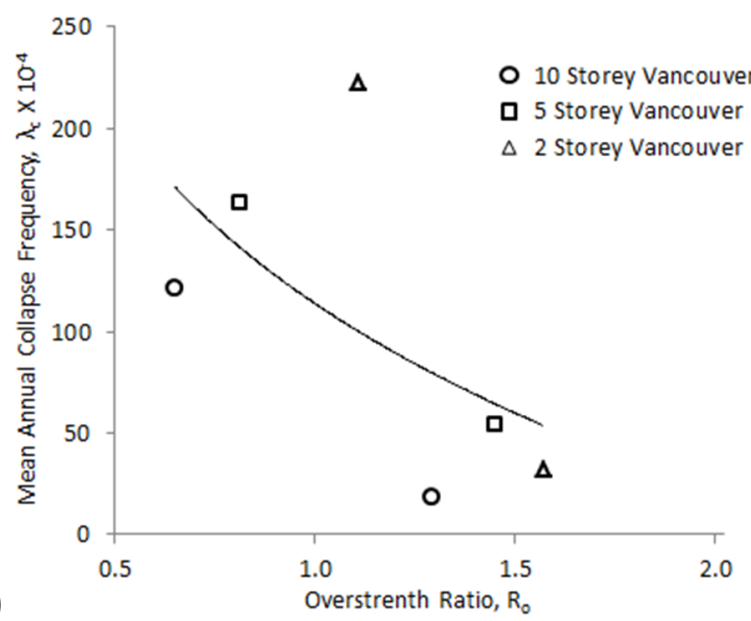

